\title{
EL RITUAL MAYA EN UN VASO DEL MUSEO REITBERG DE ZURICH
}

\section{Por Marta Foncerrada de Molina}

Entre las numerosas piezas de cerámica pintada maya del periodo Clá sico, dispersas en museos, galerías y colecciones privadas de todo el mundo, se encuentra un interesante vaso maya en el Museo Reitberg de Zürich. Según los datos que acompañan las fotos en blanco y negro que obtuve de dicho museo, el vaso procede de las tierras bajas. La al. tura del vaso es de $20.5 \mathrm{~cm}$ y su diámetro de $17 \mathrm{~cm}$. La decoración está realizada en negro, blanco, amarillo, naranja, café y rojo sobre fon. do crema. En la cédula se asienta que, estilísticamente, corresponde a la fase Tepeu in de Uaxactún (fig. 1).

El presente trabajo se ocupa exclusivamente de la escena pictórica que decora el vaso y deja a un lado la discusión sobre los problemas relativos a su procedencia geográfica y a las caracteristicas y relaciones estilísticas del mismo dentro del ámbito de las tierras bajas mayas.

$\mathrm{La}$ interpretación definitiva de muchos de los elementos del diseño pictórico y la comprensión del significado total de la escena son un tanto imprecisas; sin embargo, los motivos iconográficos y la escena en sí, poseen características sugestivas que he considerado de interés anotar en este estudio.

El vaso está decorado con una escena compuesta por seis figuras huma. nas distintas entre sí; cinco de estas figuras son naturalistas, con diferentes rasgos físicos, posturas y atavios; la sexta consiste en la representación imaginativa de un cuerpo humano en paso de danza, cuya cabeza se transforma en un mascarón serpentino de abiertas fauces de las que se proyecta el rostro naturalista de un hombre. Un templo decorado con varios simbolos religiosos, vasijas, jeroglificos y otros elemen. tos completan los motivos que integran la composición pictórica.

La reflexión inmediata que suscita esta representación es considerarla como una ceremonia de carácter religioso, ya que así Io señala el diseño del templo decorado con símbolos sagrados y la gran cabeza mítica que remata el cuello de uno de los personajes; en dicha ceremonia, se observa la presencia de miembros de la comparsa los que portan distintos disfraces y la de otros oficiantes que llevan a cabo parte del ritual de dicha festividad. 
Es interesante confrontar las caracteristicas que poseen las imágenes del vaso con la información que proporciona Fray Diego de Landa sobre las celebraciones religiosas. Según dicho autor, en estas festividades de los mayas del siglo xvi, el baile, el disfraz la máscara y las bebidas fueron prácticas que, en forma total o parcial, intervenían en el desarrollo del ritual ceremonial; ${ }^{1}$ estas prácticas pueden remontarse con cierto margen de seguridad, hasta el periodo Clásico por la evidencia que de ellas existe en la pintura y la escultura de la época.

En la composición pictórica del vaso, la figura humana con cabeza serpentina es, indudablemente, la más importante de la composición y la que proporciona la clave para interpretar, tentativamente, el contenido temático de la representación. La primera suposición, a partir del análisis inicial de las características que posee el diseño compositivo es que el pintor registró una escena ceremonial que gira alrededor de un culto serpentino personificado por el danzante con disfraz ofidio. De ser así, el artista preservó la integridad física del personaje, al colocar el rostro vivo del mismo dentro del mascarón y en un alarde realista, representar el pelo trenzado, rematado por un moño que, en ondulante movimiento, sale por atrás del propio mascarón, el que pintó de perfil, en posición vertical (fig. 4).

Si de acuerdo con la descripción anterior, la intención artística fue la representación de un danzante enmascarado colocado en un ambiente ceremonial constituido por el templo, las vasijas y los otros personajes con sus atavios, puede decirse que en esta figura, alteró las relaciones de proporción que existen entre el torso y la cabeza humana para plasmar el giro de la cabeza que, cubierta por el mascarón serpentino, se mueve violentamente al ritmo de los pasos de una danza.

Me propongo trascender esta reflexión inmediata de la escena porque considero que muchos de sus elementos sugieren otras posibilidades de interpretación. Es indudable que la composición pictórica se ocupa de un evento ceremonial; sin embargo, a pesar de que éste fue un tema manejado por los pintores de cerámica, el del vaso de Zürich no tiene paralelo con otros conocidos. El personaje de cabeza serpentina es motivo insólito en el inventario iconogrłfico de esta pintura, asi com lo son también los dos mascarones de cuyas fauces emergen el rostro del sol y el del hombre, respectivamente; a pesar de que algunos de los otros elementos pictóricos que aparecen en la escena tienen relaciones de seme-

1 Landa - Tozzer, 194I, pp. 136-149. 
janza con imágenes en otras vasijas, puede decirse que en la del vaso de Zürich el conjunto de elementos forma parte de un contexto plásticoconceptual original de difícil esclarecimiento. Es así que me interesa señalar, únicamente, algunas de las implicaciones de carácter temático y estilístico que sugiere esta representación.

La hipótesis central de las presentes consideraciones es considerar a la composición decorativa del vaso como producto de una sensibilidad artística que denomino popular para distinguirla de la del arte oficial de su época. Por otra parte, la escena refleja dos formas de expresión plástica: la realista y la simbólica y dos tipos de contenido: el ritual y el de las creencias religiosas.

Empleo el término popular para indicar la existencia de una expresión artística que no fue necesariamente promovida por la más alta jerarquía de la época sino creados en el seno de un estrato social inferior, de mayor movilidad, el que pudo comprender distintos rangos sociales y varios tipos de actividades (comerciantes, artesanos, guerreros, oficiales del estado y otros) y en el que se conjugaron múltiples experiencias e intereses humanos. Lo anterior explicaria la libertad temática y la diversidad estilistica que caracteriza a numerosos diseños en vasijas, entre las que incluyo a la que ahora me ocupa.

De acuerdo con lo anterior, la decoración del vaso de Zürich constituye un interesante documento que muestra, a mi juicio, la interpretación un tanto ingenua y localista de un evento religioso; en este caso, se trata de una expresión artística que se separó del riguroso sentido jerárquico y selectivo con que el arte oficial describió sucesos, registró imágenes figurativas o presentó simbolos religiosos.

Los elementos formales del diseño en relación a línea, proporción y sistema compositivo, asi como la caracterización de los personajes y de los símbolos no se apegan a los cánones establecidos por el arte académico. En el vaso que me ocupa, el manejo de los elementos formales y el sentido expresivo de las imágenes no es homogéneo; la línea que las delimita es, en unas, delicada y suave (por ejemplo, las que están sentadas dentro del templo, figs. 2 y 3) y en otras, el trazo apresurado, creó imágenes sintéticas, un tanto geometrizantes, rigidas y pesadas (particularmente en las manos y piernas, figs. 4,5 y 6); los rasgos físicos de los personajes manifiestan un patrón representativo idealista (los personajes dentro del templo) mientras que otros destacan por su expresivi. dad realista (por ejemplo, el hombre viejo, fig. 6). El dibujo, libre y 
espontáneo, muestra un cierto descuido y ambigüedad al delinear las figuras las que, estilísticamente, oscilan, precisamente, entre la concepción idealista de la forma y la distorsión expresiva de la misma.

La organización del espacio pictórico no está regido por los sistemas compositivos de la pintura oficial en la cual la distribución equilibrada de los elementos es siempre una constante; en este caso el interés descriptivo, en un sentido narrativo, prevaleció sobre otras consideraciones de tipo formal por lo que la composición no muestra una distribución regular de los espacios vacios y las imágenes, al yuxitaponerse, se perciben un tanto abigarradas.

Respecto al contenido de la composición, a continuación expongo algunas ideas en relación a las imágenes que la integran: los dos mascarones serpentinos de los que emergen el rostro solar y el rostro humano son, a mi juicio, la reinterpretación independiente, poco convencional, de un patrón iconográfico tradicional en el arte oficial maya; esta inde. pendencia se manifiesta por la peculiar posición que el artista le dio a la cabeza serpentina que se desplanta del cuello del danzante, la cual elevó al nivel del techo del templo y colocó frente a frente del mascarón solar que asoma de las otras fauces serpentinas. Por otra parte, es particularmente significativo que el conjunto, cabeza-humana-mascarón. serpentino se proyecte del centro de un hombre que baila. Este conjunto de imágenes parece expresar la culminación mística de una ceremonia religiosa que gira en torno a la muerte. A mi juicio, el hombre de cabeza serpentina es, en realidad, un hombre muerto; tal vez la victima en un sacrificio propiciatorio, de ahi su relevapcia en el contexto ceremonial de la escena. Este hombre aparece ya divinizado porque ha traspuesto el orden natural de los seres vivos; su rostro surge del monstruo terrestre y su cuerpo posee los rasgos serpentinos que lo identifican y lo hacen parte del inframundo.

En relación a lo anterior, me interesa sugerir la posibilidad de considerar al personaje anterior como la victima de un rito sacrifical por decapitación. La verificación de esta hipótesis rebasa los limites que me he trazado para el presente trabajo, sin embargo, fundamento la hipótesis en la evidencia que existe sobre la práctica de este rito de sacrificio durante el Clásico, según consta por la representación de cabezas trofeo y de cabezas humanas como objeto de culto, las que aparecen tanto en la escultura como en la pintura de la época.

La representación de la víctima del sacrificio por decapitación en. un 


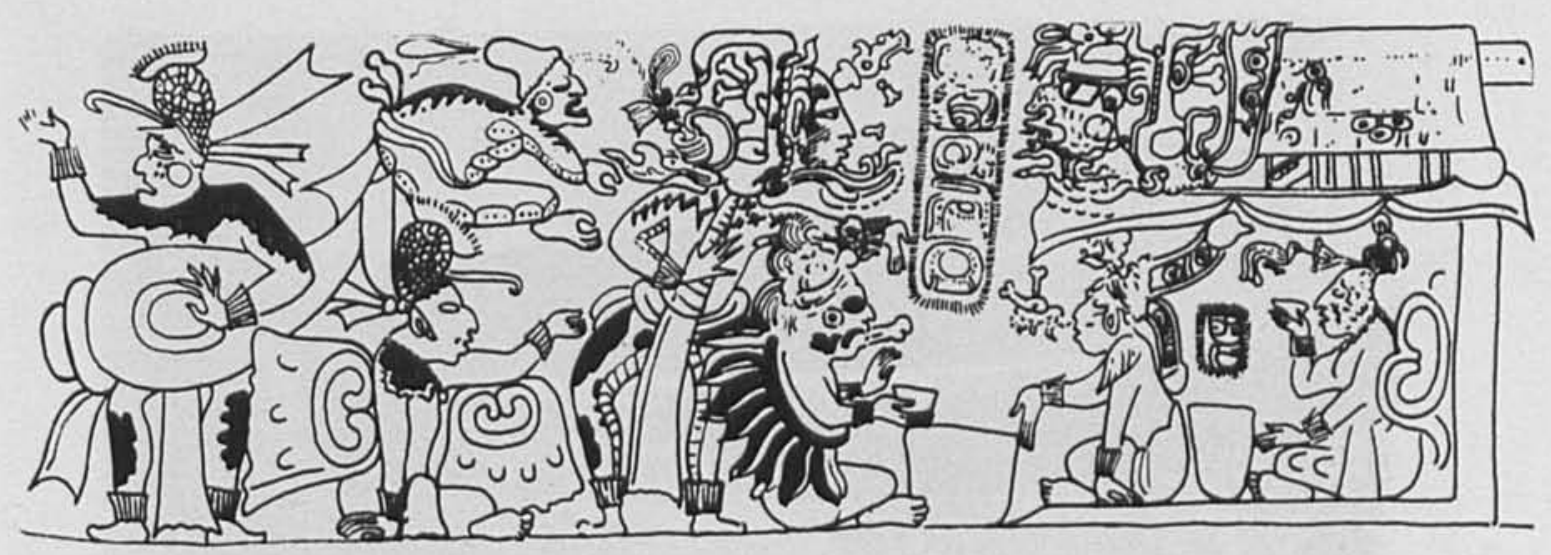

1. Dibujo extendido del vaso 
DOI: http://dx.doi.org/10.22201/iie.18703062e.1974.43.987

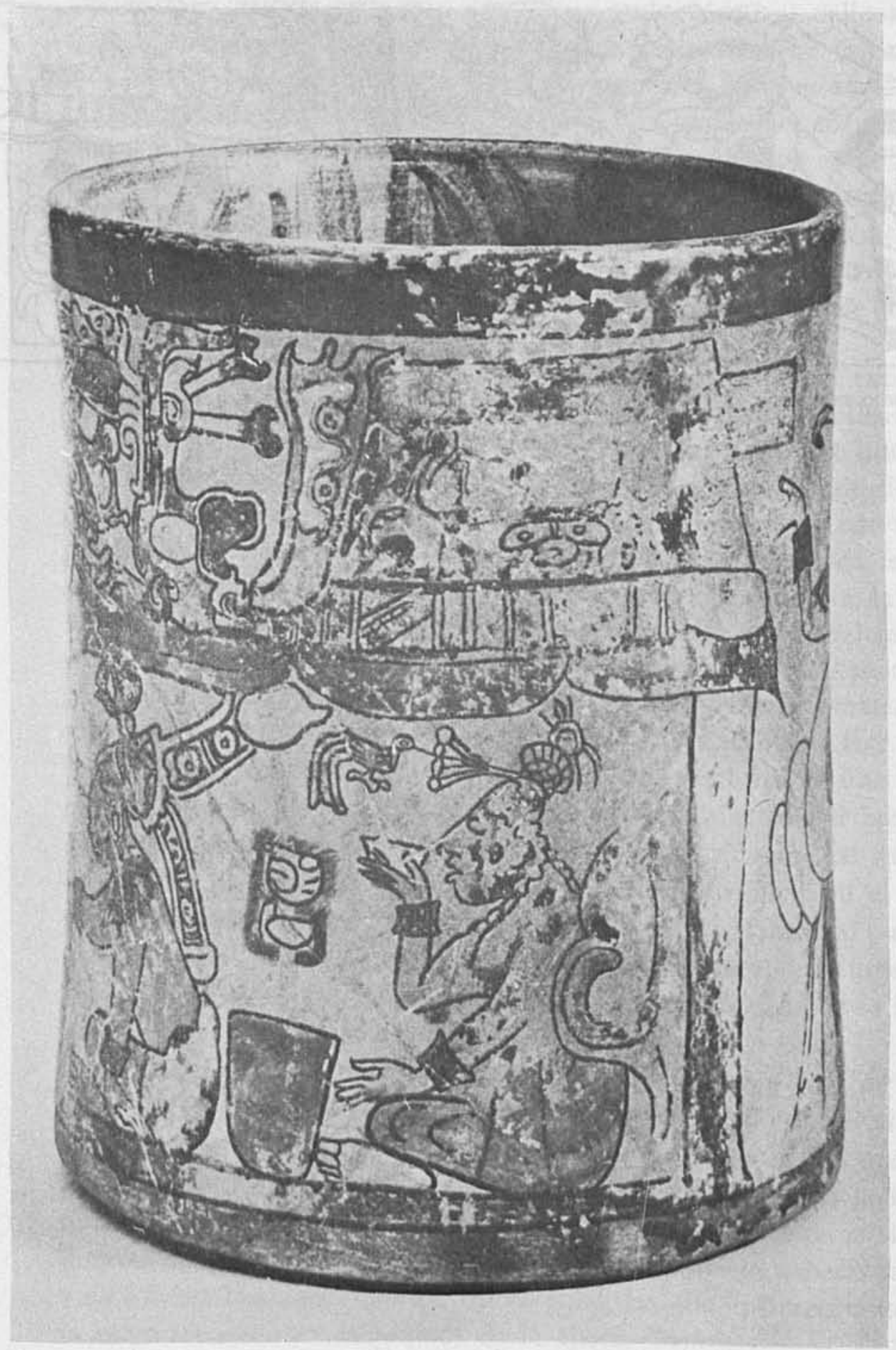

2. Vista parcial del vaso 
DOI: http://dx.doi.org/10.22201/iie.18703062e.1974.43.987

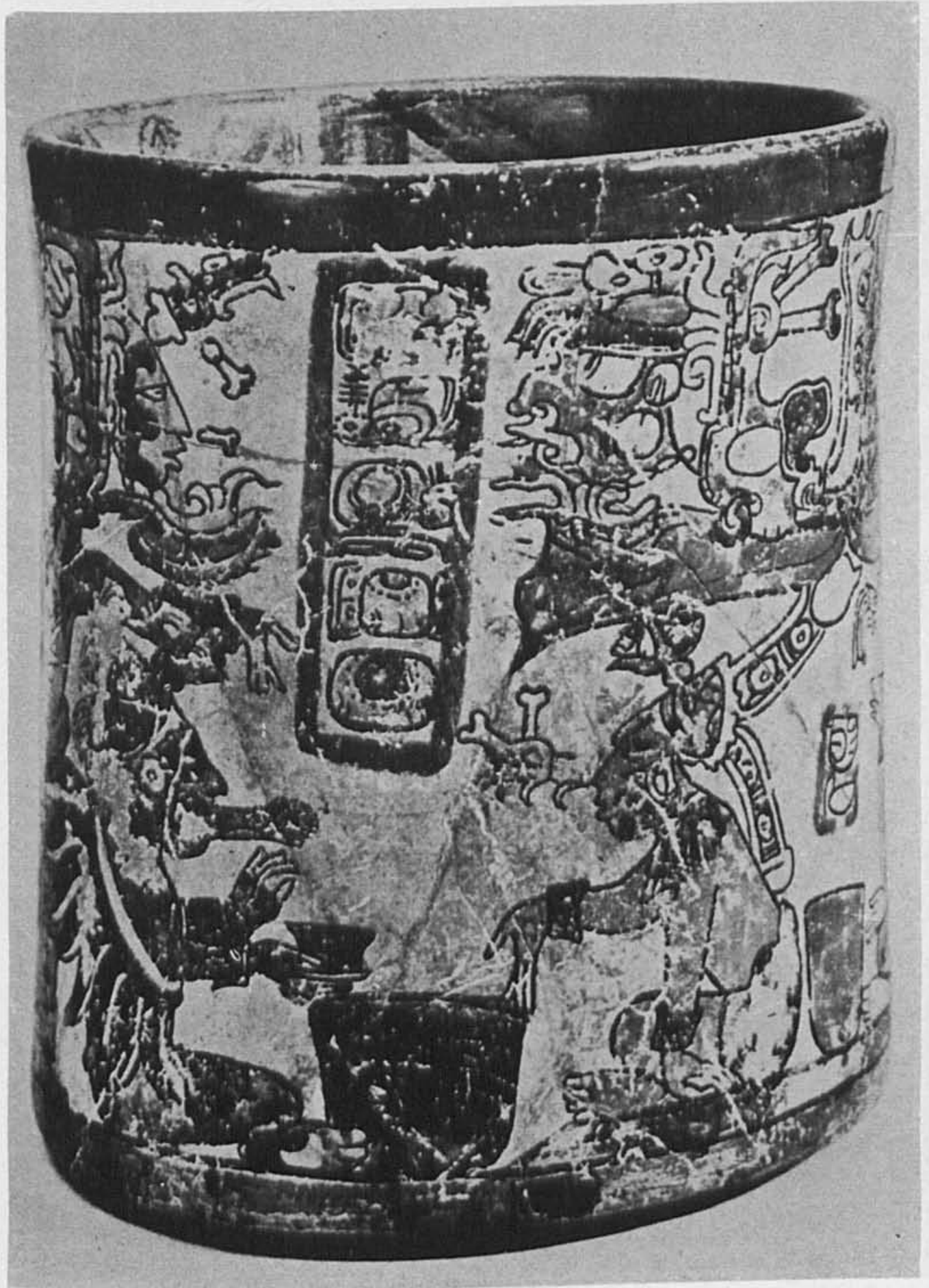

3. Vista parcial del vaso 
DOI: http://dx.doi.org/10.22201/iie.18703062e.1974.43.987

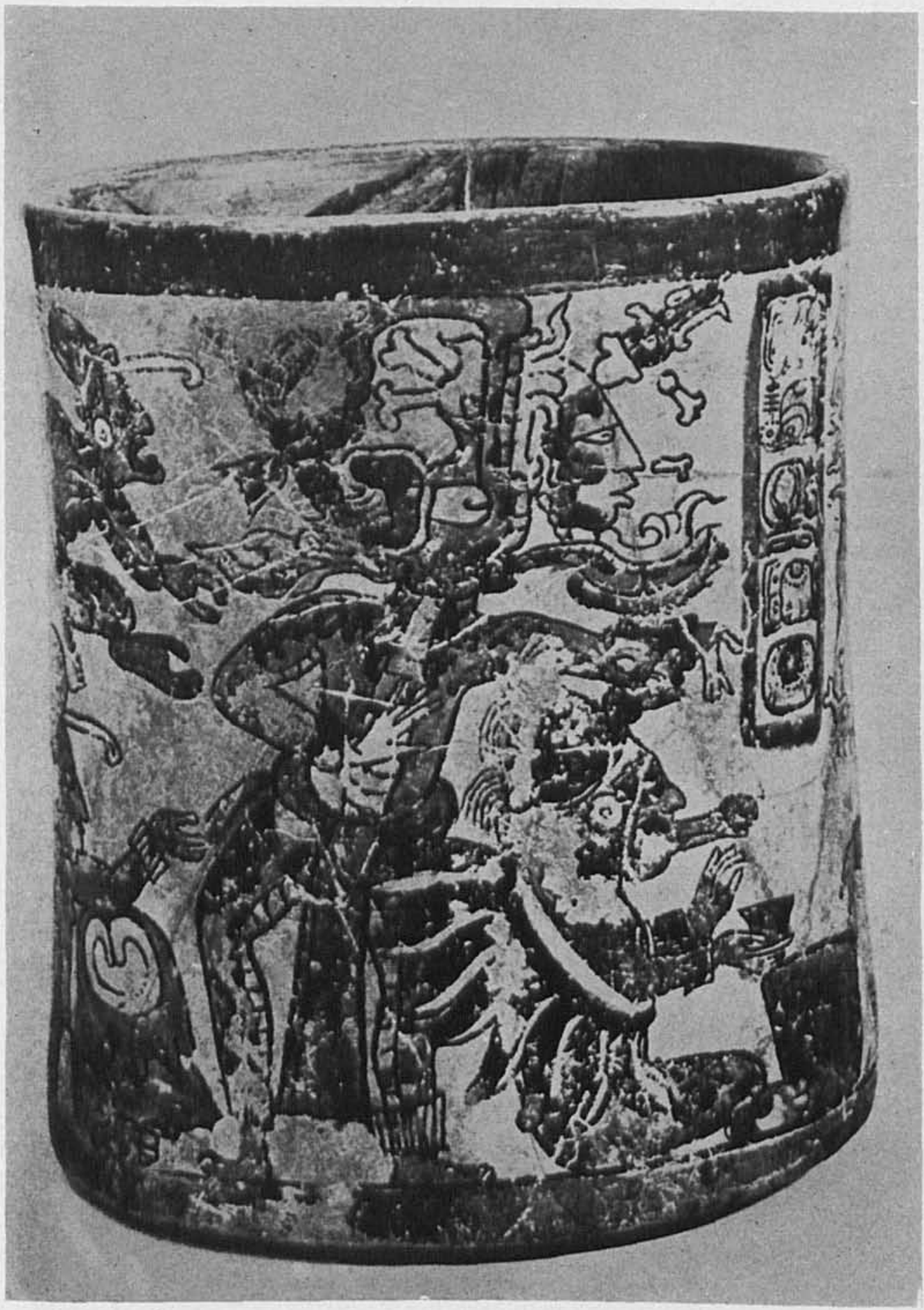

4. Vista parcial del vaso 
DOI: http://dx.doi.org/10.22201/iie.18703062e.1974.43.987

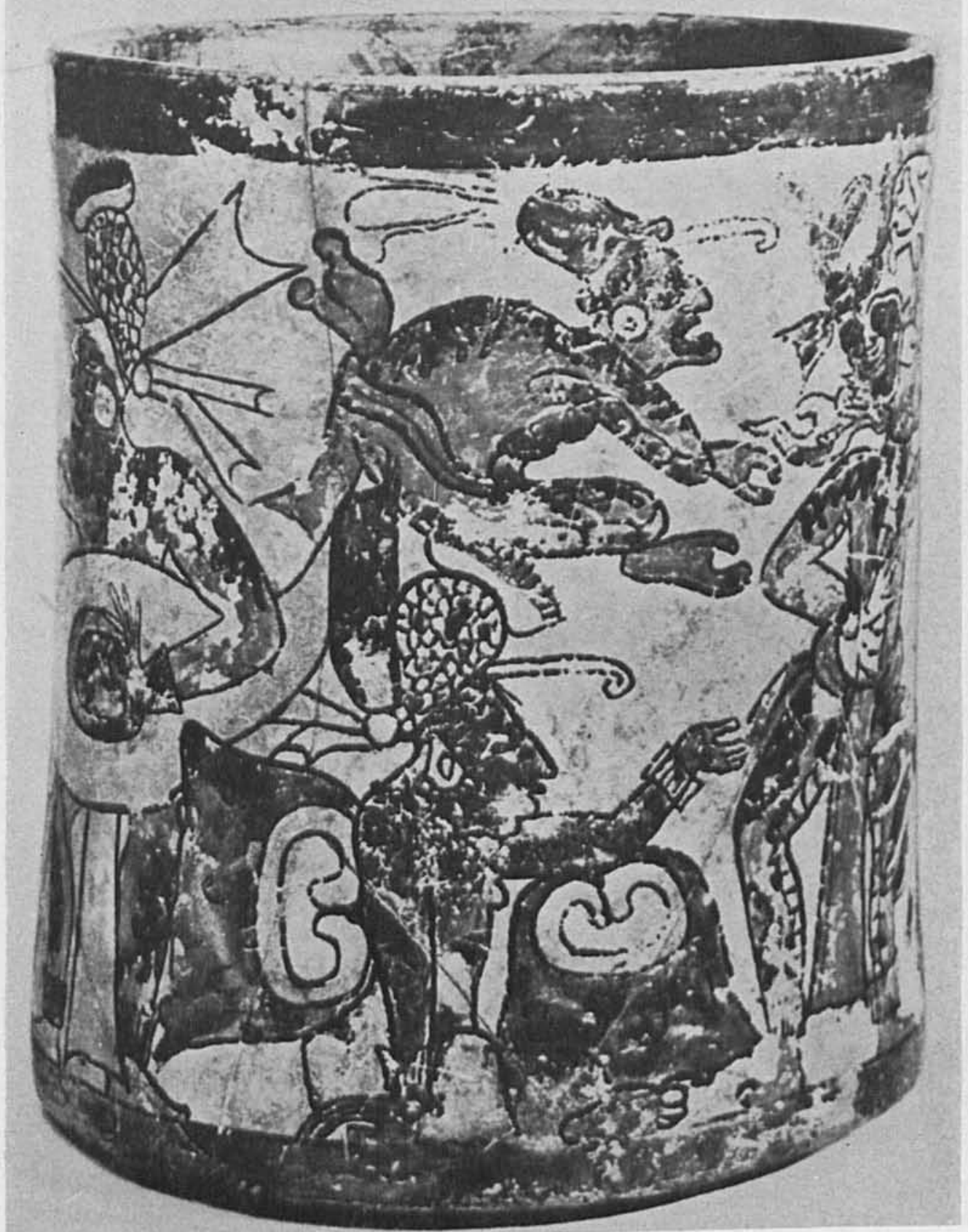

5. Vista parcial del vaso 
DOI: http://dx.doi.org/10.22201/iie.18703062e.1974.43.987

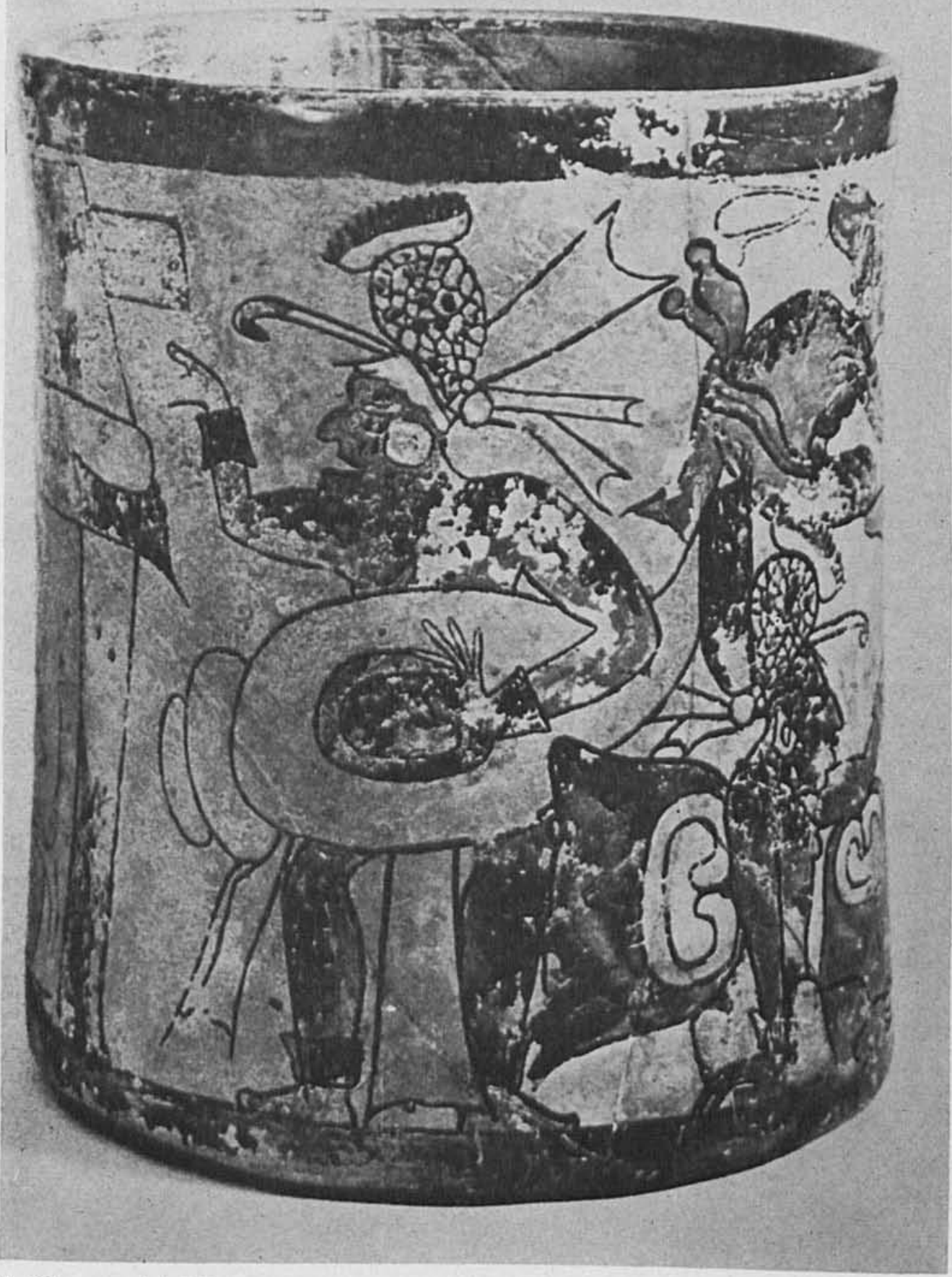

6. Vista parcial del vaso 


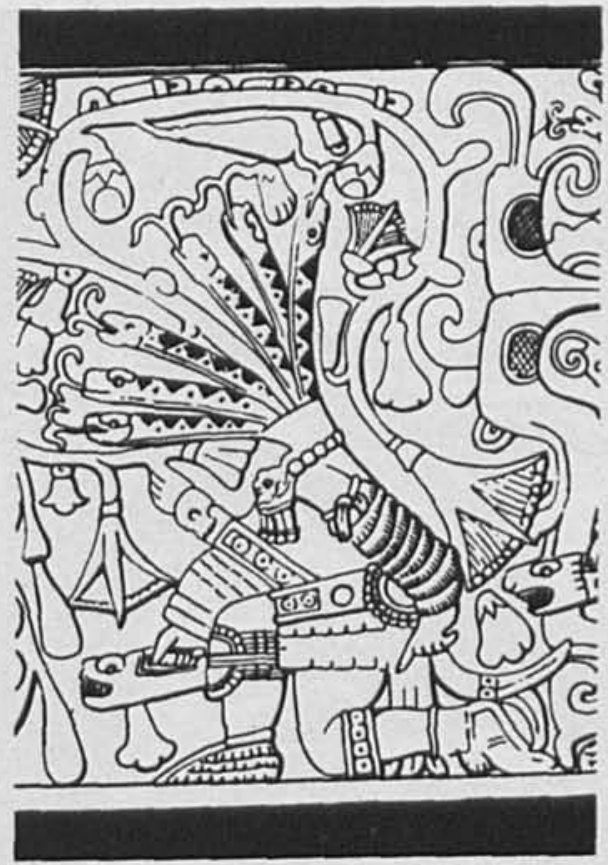

7. Chichén Itzá Banqueta oeste del Juego de Pelota. Detalle (Tozzer, 1957. Fig. 474)

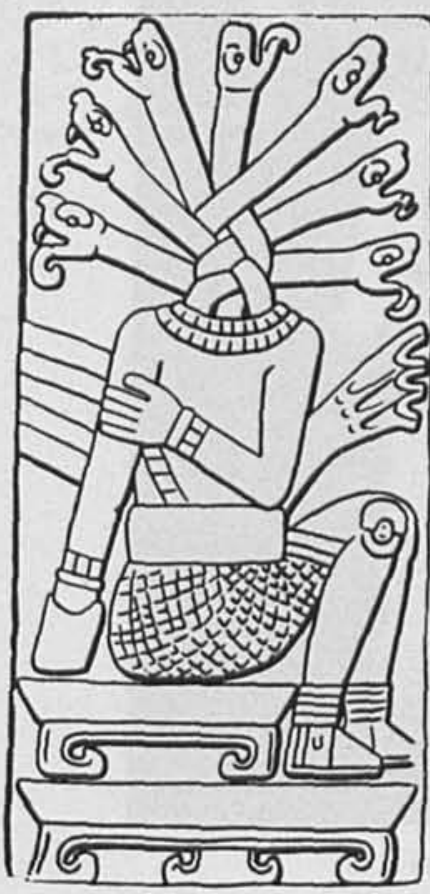

8. Lápida de Aparicio, Veracruz (Tozzer, 1957. Fig. 475)

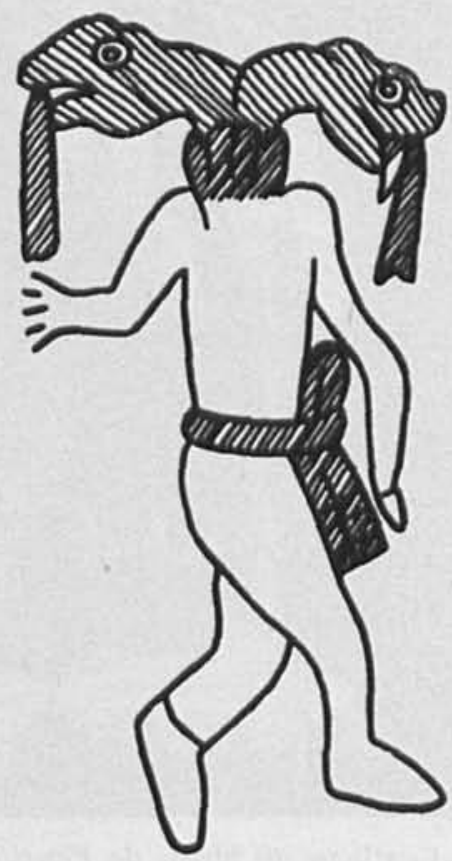

9. Códice Aubin. Página 15. Detalle (Tozzer, 1957, Fig. 476) 


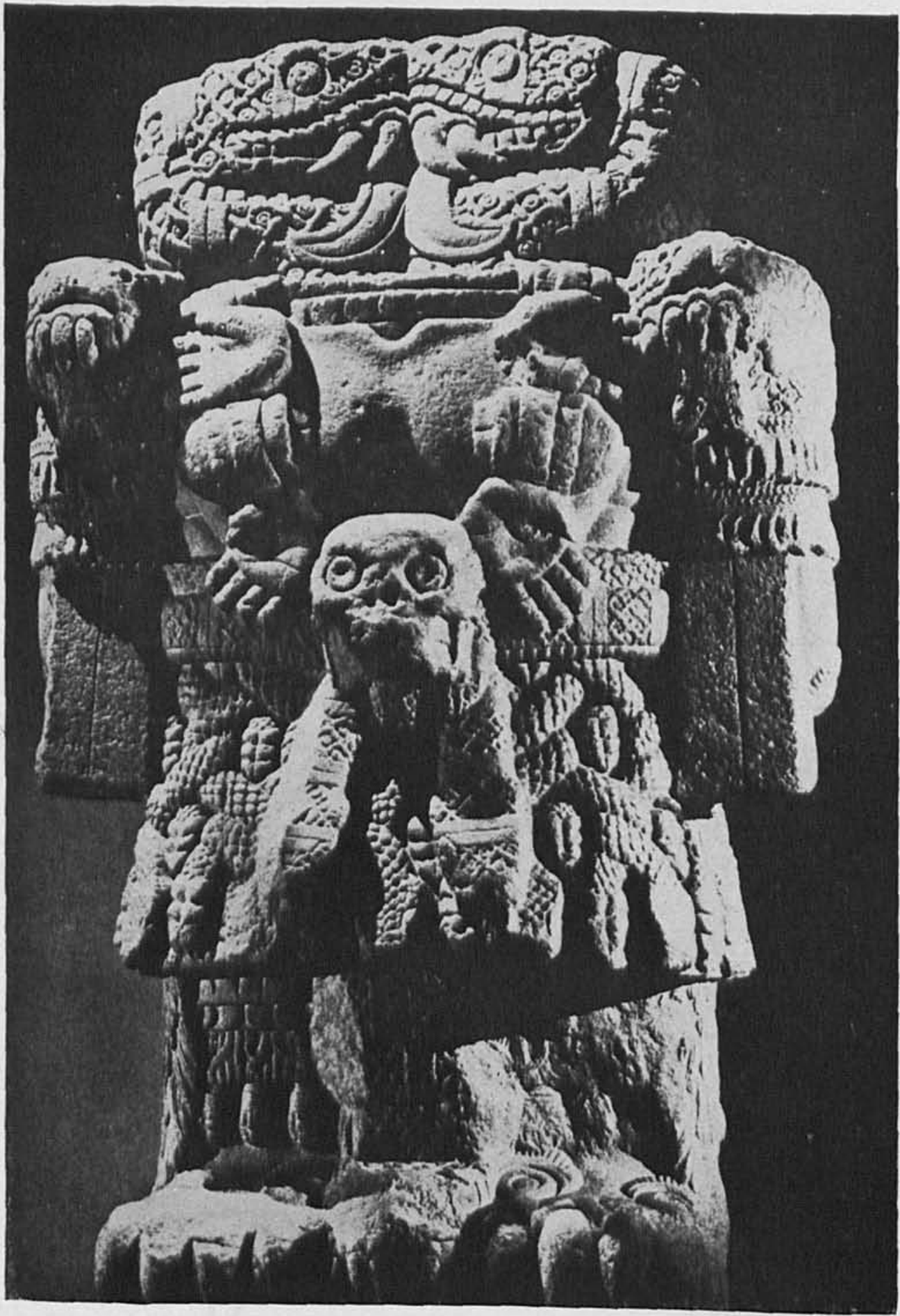

10. Coatlícue 40 Siglos de Plástica Mexicana, vol. 1, 1969. Lámina 186 
DOI: http://dx.doi.org/10.22201/iie.18703062e.1974.43.987

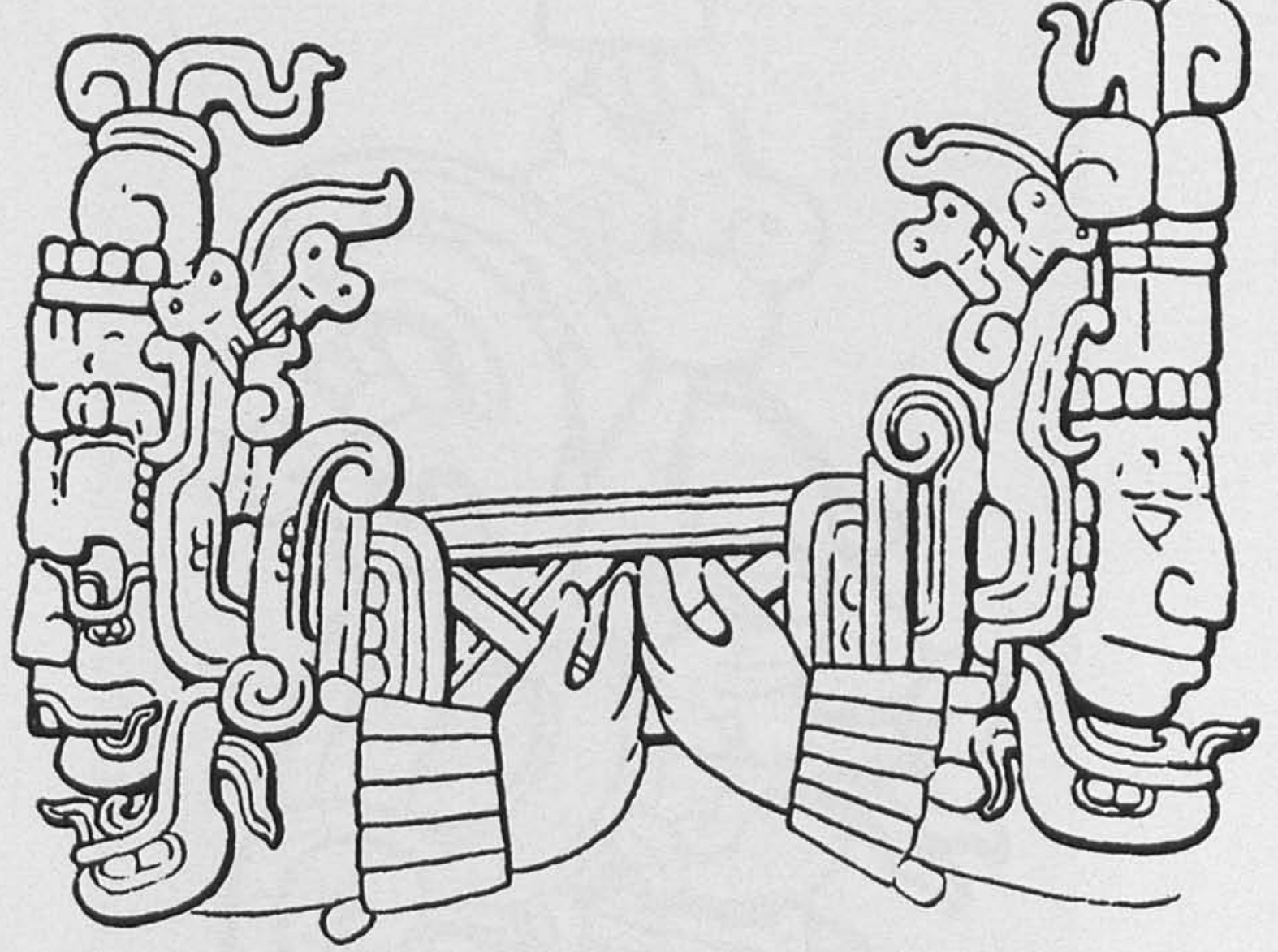

11. Barra Ceremonial, Estela 6 de Naranjo. (Proskouriakoff, 1960. Fig. 31 h) 
DOI: http://dx.doi.org/10.22201/iie.18703062e.1974.43.987

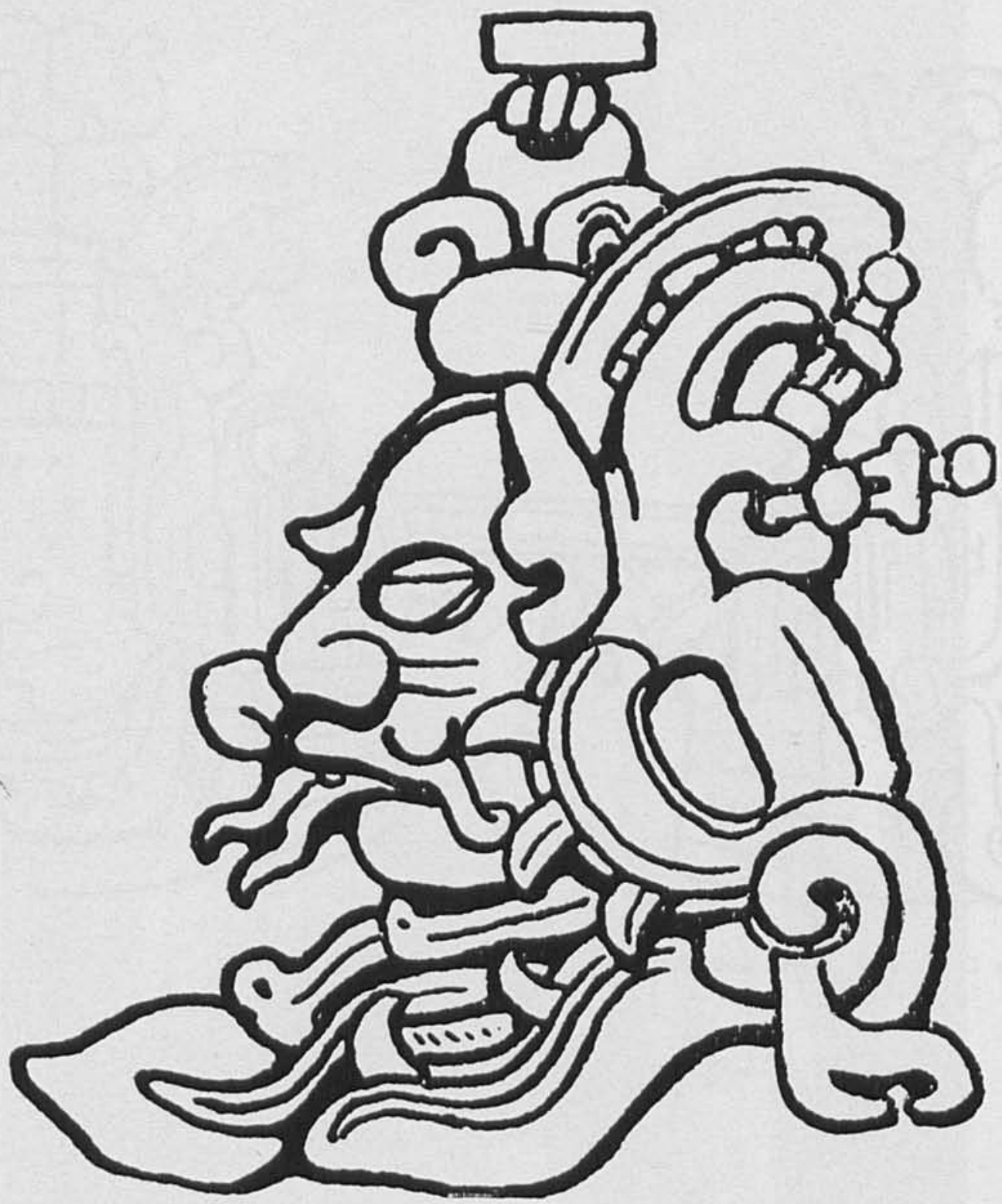

12. Tikal. Estela 1. Detalle (Spinden, 957. Fig. 88) 
DOI: http://dx.doi.org/10.22201/iie.18703062e.1974.43.987

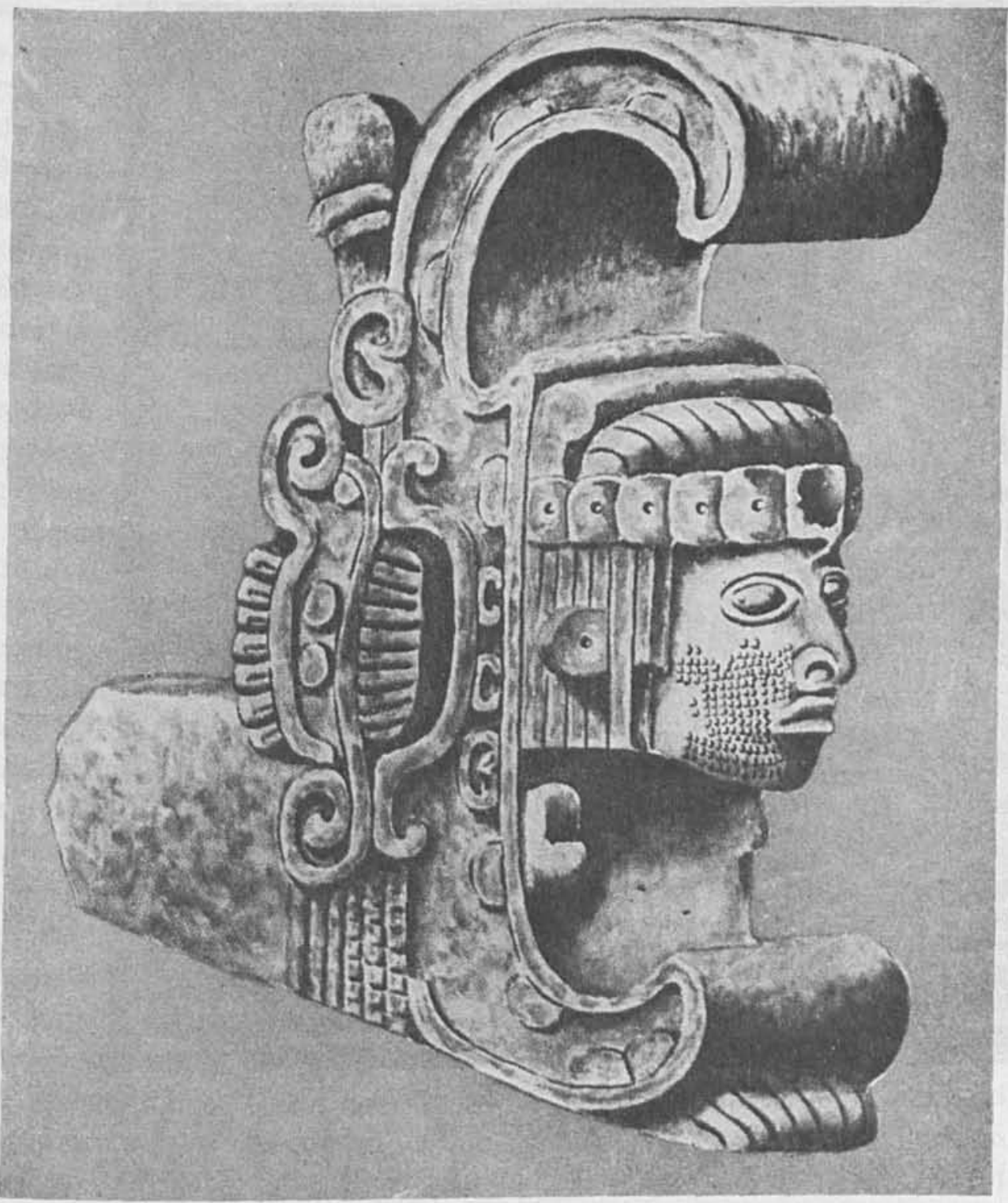

13. Uxmal. "Reina de Uxmal" (Guía Oficial de Uxmal, INAH) 


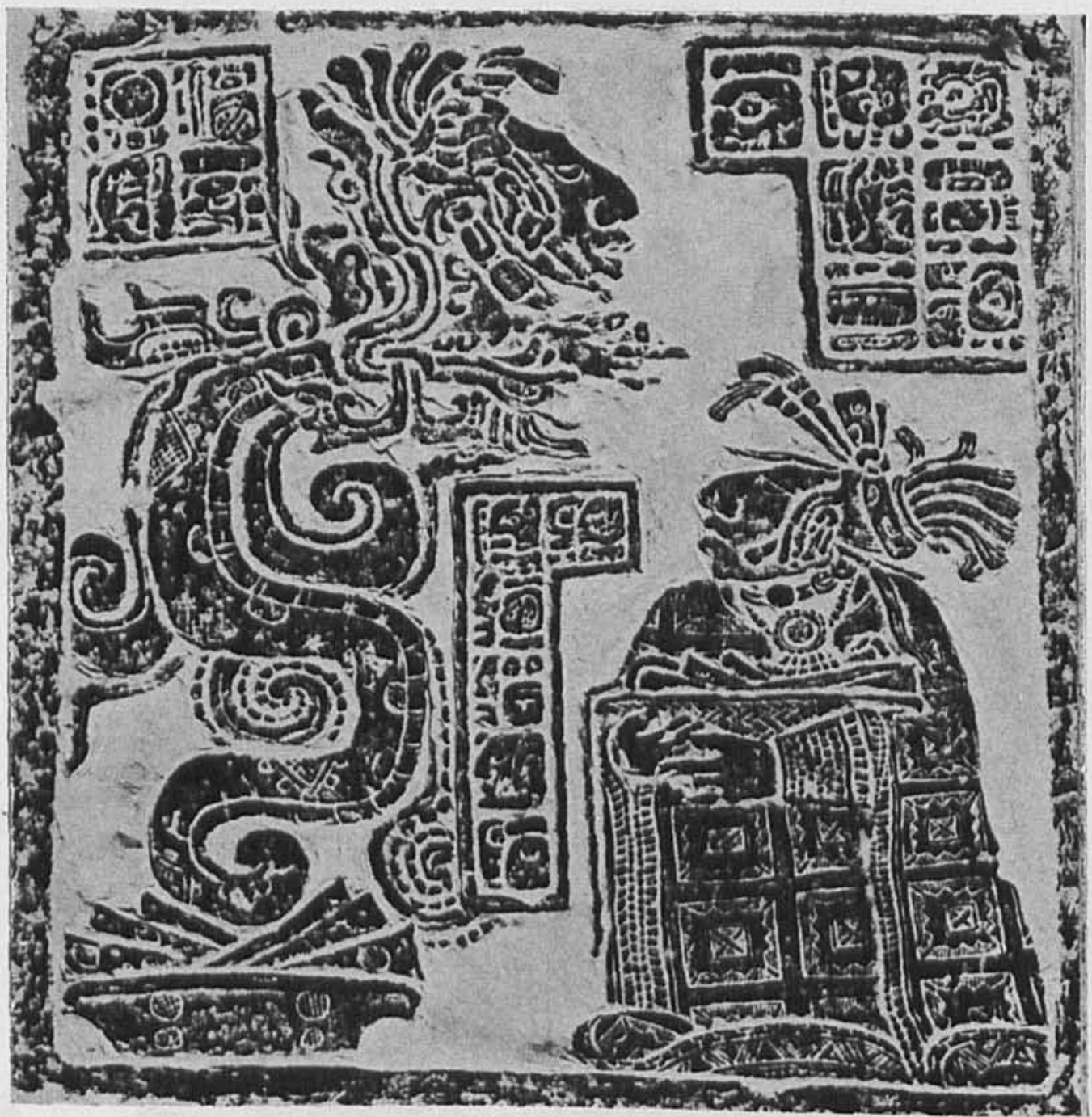

14. Yaxchilán. Dintel 15 (Greene, Rands y Graham, 1972. Lámina 33) 
nivel simbólico y a la vez explícito, se ha manifestado en el arte mesoamericano por la representación del cuerpo humano decapitado de cuyo cuello se proyectan serpientes; esto se observa en el jugador de pelota de Chichén Itzá (fig. 7), en el personaje de la Lápida de Aparicio (fig. 8) en Veracruz, en varias representaciones en códices (fig. 9) y aun en la Coatlique azteca (fig. 10). Las barreras del tiempo y la distancia impiden relacionar directamente este tipo de imágenes con la del vaso de Zürich por Io que no puedo dejar más que en el nivel de hipótesis la idea de que una concepción análoga hubiese determinado la representación en el vaso de un personaje de cuyo cuello aparentemente degollado se desplanta la cabeza mitica de una serpiente. Sirvan estas digresiones, simplemente, para apuntar algunos problemas de iconografía que suscita el análisis de la decoración del vaso.

Respecto a los otros elementos que integran la composición, encuentro que el diseño del templo muestra claramente el tema o sentido re. ligioso de la escena (fig. 2 y 3). El motivo arquitectónico no es frecuente en la pintura de vasijas; aparece, en ocasiones, sugerido por el trazo de plataformas, postes y aun cortinajes, pero en ningún caso, fuera del vaso de Zürich, se dibujo con la totalidad de sus partes. El techo de este templo remata en la cabeza mitica de una serpiente en cuyas fauces se asienta el mascarón antropomorfo del dios solar; la identificación de éste es inequívoca por el gran ojo cuadrado, la mirada estrábica, la nariz roma y el diente limado al frente que sobresale del labio superior; corona la cabeza del dios un sombrero de ala corta decorado en la parte superior con cuentas y lazos; este detalle en el atavio no corresponde a la manera ortodoxa de cubrir la cabeza del dios solar, lo que muestra una cierta independencia y libertad decorativa del pintor en el" manejo de un símbolo religioso tradicionai. La cabeza serpentina se prolonga hacia arriba, por un cuerpo ondulante decorado con el simbolo de Venus, y se extiende, en el nivel inferior del techo, para transformarse en la imagen sugerida de una banda celeste. Encima de esta banda se advierte claramente el diseño del glifo Ahau una de cuyas connotaciones simbólicas es el sol.

El diseño prosigue con dos personajes, un hombre y una mujer; el uno detrás del otro y separados entre si por una gran vasija cillndrica; ambos se sientan, con las piernas cruzadas dentro del templo, bajo los ondulados cortinajes que penden del techo. Los dos están con los ojos cerrados en actitud de trance; según la información que a este respecto 
dan las fuentes documentales, el estado de trance caracteriza a un sinnúmero de actos rituales en las ceremonias mayas, que se propiciaba, frecuentemente, por la ingestión de bebidas fermentadas;: la imagen femenina, precisamente, está en actitud de beber ya que sostiene en la mano, levantada frente al rostro, un pequeño recipiente. La participación de la mujer en las ceremonias rituales de los antiguos mayas es frecuente en numerosas representaciones del arte monumental maya (Bonampak, Yaxchilán, Palenque), así como también existen referencias en las fuentes documentales sobre la intervención de la mujer en diversas ceremonias religiosas. El rango religioso de esta imagen femenina está posiblemente señalado por el torso desnudo, el caracol cortado que porta en la espalda y por el colibri que mete su largo pico en los pétalos de la flor que adorna la parte anterior de su penacho. El colibrí tiene una asociación simbólica con el sol y podría indicar, en este caso, una relación explícita con la deidad solar, representada en el nivel más alto del templo. ${ }^{3}$

El personaje sentado dentro del templo está en relación de comunicación con la figura que, frente a él, sostiene en la mano un recipiente que casi apoya en el borde de una gran vasija que los separa entre sí. El rostro naturalista de este personaje se alteró por medio de un adorno bucal que parece abarcar el labio superior y el inferior y se proyecta al frente en forma de hueso o de una cabeza naturalista de serpiente; porta, además, hermosa capa corta de plumas que le resbala de los hombros. La mirada alerta, la postura ritual de la mano izquierda y el ademán de la derecha con el que parece extender el recipiente al personaje invidente frente a sí, permite suponer que el papel que esta figura desempeña en la ceremonia es el de proveedor de las bebidas rituales requeridas para el desarrollo del evento ceremonial.

El segundo grupo de figuras consiste en una de pie, otra sentada y otra en postura sedente que, ingrávida, está colocada encima de ésta. La figura de pie es la de un hombre viejo desdentado con el cuerpo aparentemente decorado con grandes manchas; los brazos y las piernas están en actitud dinámica y sostiene al frente, en posición transversal, un gran caracol. El otro personaje tiene el rostro de un hombre joven; de cada uno de sus brazos se proyectan, una hacia abajo y otra extendida hacia atrás, dos grandes alas de mariposa, Las dos figuras portan

2 Ibid. p. 165.

3 Thompson, 1932, p. 120. 
turbantes hechos de semillas decorados en la parte superior con una flor de muchos pétalos.

Las posibilidades de establecer las asociaciones simbólicas que plantean estos dos personajes tienen que basarse en el caracol y en la mariposa que caracterizan, respectivamente, el atavio de cada uno de ellos. Ambas figuras son, a mi juicio, danzantes o miembros de la comparsa ritual que habitualmente intervenía en el desarrollo de todo acto ceremonial. El caracol que adorna al danzante de pie podría tener una connotación de inframundo de acuerdo a la interpretación que se le ha dado a éste en la iconografía del periodo Clásico. $*$ Respecto a las alas de mariposa que adornan al otro personaje no encuentro una asociación explícita en otras expresiones del arte y el pensamiento maya que me permitieran entender su significado; a menos que, para no considerarla como un disfraz zoomorfo diseñado con un sentido puramente decorativo, lo refiera a una de las significaciones que la mariposa tiene en la religión azteca; la de simbolizar el alma del guerrero muerto en batalla $o$ por sacrificio ${ }^{5} 0$, con cierta reserva, hacer extensiva a la mariposa la concepción religiosa maya sobre el retorno a la tierra de los muertos y también de algunos dioses (los bacabs) en la forma de insectos. ${ }^{6}$

El tercer personaje que flota en el espacio, es un hombre viejo, sin dientes, mandíbula prominente, pintura alrededor de los labios y espalda encorvada; ciñe la cabeza con sombrero de copa alta y ala corta de la que se proyecta al frente un gancho. Este sombrero, así como el que porta el mascarón solar en el remate del templo, posee un carácter popular que parece corresponder a una forma de atavío regional usado por la gente del pueblo ya que se diferencia, notablemente, de los elaborados tocados que ornamentan las imágenes representativas del arte oficial.

El contorno del cuerpo del hombre viejo está decorado por manchas que, en secciones, se convierten en claros diseños serpentinos. Esta decoración simbólica y la posición flotante de la imagen pudieran indicar que la intención del artista fue la de representar un dios. Sin embargo, no ostenta los símbolos que como tal pudiesen identificarlo ni tampoco aparece en un contexto definido para asociarlo con alguno de los dioses viejos conocidos del panteón maya. De acuerdo con los rasgos físicos del

Ibid. 1960, p. 278.

5 Beyer, 1965, p. 465.

- Thompson, 1960, p. 85. 
rostro podria tentativamente relacionarse con el dios $L$ asociado al día Akbal, a la noche y a la oscuridad ${ }^{2}$ en los que está implícita la idea de inframundo y, por lo tanto, también la de la muerte. A pesar de estas consideraciones, me parece que no puede atribuirsele el rango de dios al hombre viejo de la escena.

Parece más plausible referir la imagen a la de un participante real en la ceremonia cuya colocación en el espacio pictórico obedeció al deseo del pintor por llenar un vacio, o posiblemente, al empleo de un sistema de perspectiva vertical para sugerir distancia física entre esta figura y las demás. Por otra parte, la intervención del hombre viejo en las ceremonias religiosas de los mayas está atestiguado por el arte monumental y por las fuentes documentales, lo que me permite suponer que dicha representación en la vasija no es la de un dios sino que registra a un miembro del grupo ceremonial.

Es indudable que todos los motivos iconográficos, arriba discutidos, plantean relaciones formales y temáticas novedosas y de dificil interpretación. La manera como aparecen representados los mascarones serpentinos en la decoración del vaso representan una versión poco ortodoxa del empleo tradicional que el arte oficial hizo de ellos. En muchas de las manifestaciones del gran arte maya, la representación de rostros humanos y divinos emergiendo de fauces serpentinas, se repite en distintos diseños, materiales y fonmatos; en unos, las cabezas se encuentran colocadas en cada uno de los extremos de un elemento central que representa el ondulante cuerpo de la serpiente o lo transforma en la rigidez convencional de una barra o banda. En otros, rostros humanos integra. dos a las fauces de un mascarón serpentino o a la representación de una serpiente completa, fueron motivos iconográficos que se repitieron en relieves y en esculturas integradas a la arquitectura. Las imágenes arriba mencionadas son imágenes fantásticas que, aunque extraidas de la realidad, están más allá de la condición física de los seres naturales; el hombre aparece en éstas en intima relación con la divinidad, la que desmaterializó su cuerpo y sólo preservó el rostro y en ocasiones parte del torso (figs. 10, 11 y 12).

La idea de inframundo y por ende de muerte y resurrección están, a mi juicio, implícitas en estos símbolos, expresión plástica de creencias que debieron transformarse en vivencias religiosas de profunda raigambre emotiva, a través de diversas prácticas rituales. Por ejemplo, en va.

T Schellhas, 1904, pp. 34-35. 
rios dinteles de Yaxchilán el culto a los muertos, posible evocación del antepasado, propiciado por ritos de sacrificio humano por derramamien. to de sangre, se manifestó en el arte escultórico, precisamente, por la representación de rostros que surgen de cabezas serpentinas (fig. 13).

En la decoración del vaso advierto una sensibilidad artística y religiosa que no tuvo reparo en alterar el complejo simbólico mascarón-rostro del hombre, al colocarlo sobre el cuerpo de un danzante.

El mascarón divino, incluido en el contexto descriptivo más amplio de la composición pictórica, aparece desacralizado, desposeído de la dignidad simbólica que le era característica dentro de la plástica oficial; el pintor del vaso rompió la distancia metafísica que, en este arte, simpre lo representó desvinculado de la imagen realista del cuerpo humano.

Es posible que los dos mascarones serpentinos sean imágenes del dios Itzamná, concebido éste como el monstruo con formas ofidias y de cocodrilo, que entre otras atribuciones, simboliza la comunicación mística entre el cielo y la tierra ya que habita en ambas regiones. El carácter terrestre de Itzamná está expresado por los diseños vegetales que forman la mandíbula inferior y el remate posterior de la cabeza del mascarón que corona el cuerpo humano. La asociación con la tierra tal vez está indicada por los dos jerogifficos de Imix, dios que simboliza a la tierra como monstruo que da la abundancia y fertilidad y acoge a los muertos. La otra cabeza serpentina en la composición pareciese señalar el aspecto celeste de Itzamná.

De acuerdo con lo anterior, la inclusión en la composición de formas simbólicas religiosas de profundo arraigo en el arte oficial maya y la peculiar versión que el artista hizo de ellas, podria explicarse, como ya lo dije anteriormente, porque surgieron como expresiones artísticas en un estrato social que, a falta de otro término, podria llamarse la clase media maya; sobre la existencia e importancia de esta clase media, durante el Clásico se han hecho interesantes comentarios, en los últimos años, por investigadores interesados en el estudio de la dinámica socioeconómica de la civilización maya. Si el artista de la vasija provino de esta clase social, es posible suponer que debio estar familiarizado con la simbologia del arte oficial; sin embargo, su posición en la escala social y el que, posiblemente, no hubiese sido un artista especializado bajo la dirección de la alta jerarquía, le permitió liberarse del compromiso de acatar las normas establecidas para el arte oficial; las imágenes 
y la secuencia narrativa de la escena pictórica, a mi juicio, dan fe de su talento anecdótico, altamente expresivo.

En conclusión, me parece de singular importancia sugerir que el vaso de Zürich es representativo de un grupo importante de vasijas mayas que no deben clasificarse dentro de la categoria de ceremoniales en tanto que éstas sean consideradas como las que sirvieron para cumplir funciones exclusivamente funerarias o relacionadas con formas de culto oficial. A mi juicio, muchas de las representaciones pictóricas en vasijas del Clásico maya son documentos que se refieren a hombres, hechos y creencias, y provienen de un medio social distinto al de las formas de pensamiento, la sensibilidad y el estrato social del que surgió el arte oficial.

Sirvan las reflexiones anteriores para señalar los problemas que plantea a la investigación del arte maya la existencia de un arte popular, el que debió florecer paralelo al gran arte oficial. Este arte se expresó en la pintura de vasijas con un vocabulario plástico más expresivo que el del arte oficial y registró hechos y creencias más cercanos al palpitar de Ia vida de la comunidad. 


\section{B I B L I O G R A F I A}

Beyer, Hermann

1922

Coc, Michael D.

1973

Landa, Fray Diego de 1938

Proskouriakoff, Tatiana 1964

Schellhas, P.

1904

Thompson J.E.S.

1932

1960

1970

Tozzer, Alfred M.

1941

1957

Willey, Gordon Roy

1979
"La Mariposa en el Simbolismo Azteca", El México Antiguo. Tomo $\mathrm{x}, 1965$. Sociedad Alemana Mexicanista, México.

The Maya Scribe and His World. The Grolier Club, New York.

Relación de las Cosas de Yucatán. 7a. edición. Introducción y notas de Héctor Pérez Martinez. México.

"Historical Dates in the Inscriptions of Yaxchilán", Estudios de Cultura Maya. Vol. IV, UNAM.

"Representations of Deities in the Maya Manuscripts", Papers of the Peabody Museum of Amer., Arch. and Eth. Vol iv, núm. 1. Harvard University, Mass.

"The Humming Bird and the Flower", Maya Soc. Quart. Baltimore.

Maya Hieroglyphic Writing. University of Oklahoma Press. Norman.

Maya History and Religion. University of Oklahoma Press. Norman.

"Landa's Relación de las Cosas de Yucatán. A. Translation", Papers of the Peabody Museum of Amer. Arch. and Eth. Vol. xvir. Edited with notes by Alfred $M$. Tozzer. Harvard University.

"Chichen Itza and its Cenote of Sacrifice", Memoirs of the Peabody Museum of Arch. and Eth. Vol, xir. Harvard University, Cambrige.

"Demitri B. Shimkin - The Maya Collapse: A Summary View", The Classic Maya Collapse. Edited by T. Patrick Culbert. A School of American Research Book. University of New Mexico Press. Albuquerque. 